Економічні науки". - Серія "Облік і фінанси". - Випуск 15 (57). - 2018.

3. Конєва Н.О., Шаповалова I.О. Шляхи покращення фінансового стану підприємств [Електронний ресурс] - Режим доступу: http://mdu.edu.ua/spaw2/uploads/files/16_13.pdf.

4. Кулик Л.С. Діагностика фінансового стану підприємства як основа його економічної безпеки. Зб. наук. пр. «Економічні науки». - Серія «Облік і фінанси». - Луцьк: ЛНТУ, 2017.

5. Рудницька О.М., Біленська Я.Р. Шляхи покращення фінансового стану українських підприємств / Рудницька О.М., Біленська Я.А. // Вісник «Логістика», Львів: Вид-во НУ ЛП, 2013. - № 649 - С. 132-138.

6. Цар О.З. Аналіз динаміки фінансового стану підприємства України / О.3. Цар // Зовнішня торгівля: економіка, фінанси, право. - 2016. - №3. - С.221-238.

*УДК 65.041.1:338.48

Квасній Л.Г., к.е.н, доцент

Дрогобицький державний педагогічний університет ім. I. Франка Щербан О.Я., к.е.н, доцент

ВСП НН ІППТ НУ «Львівська політехніка»

\title{
ЧИННИКИ АНТИКРИЗОВОГО УПРАВЛІННЯ ПІДПРИЄМСТВ ТУРИСТИЧНОї ІНДУСТРІї
}

У статті проаналізовано сучасний стан розвитку та проблеми туристичної діяльності в Україні. Обгрунтовано доцільність застосування антикризового управління на вітчизняних підприємствах туристичної індустрії. Запропоновано антикризові заходи розвитку туризму, що сприятимуть вирішенню наявних проблем.

Ключові слова: кризовий стан, антикризове управління, туристична галузь.

Kvasniy L., Shcherban O.

\section{FACTORS OF ANTI-CRISIS MANAGEMENT OF ENTERPRISES OF THE TRAVEL INDUSTRY}

The purpose of the article is to study anticrisis management of tourist organizations and enterprises as a means of forming their competitive advantages on different levels of management. As a result of analysis and generalization of studies conducted by domestic and foreign scholars, the main features of the development of tourism were determined, main directions of improving the competitiveness of tourism activities were systematized and crisis management measures for tourism enterprises

* Квасній Л.Г., Щербан О.Я. 
and organizations were proposed. The study analyzed the current status and problems of tourism in Ukraine. The expediency of application of anticrisis management on domestic tourism enterprises and organizations was justified. Anticrisis measures for tourism development were proposed. Namely: of strategic, economic and financial, organizational, innovation, investment, marketing and human resource kind at the enterprise, region and state level. That will solve the existing problems and improve the competitive advantages of tourism organizations and businesses.

It proves that crisis sources in tourism fall into internal and external risks that are determined by the influence of anthropogenic and natural determinants. Research results show that the impact of natural sources of risk in tourism and sources of risks of social and political nature has increased significantly in recent decades. Consequently the article underlines the necessity in collaboration in the field of crisis management in tourism at the level of international tourism organizations, regional and national tourism organizations.

Key words: crisis situation, crisis management, tourism industry.

Квасний Л.Г., Щербан О.Я.

\section{ФАКТОРЫ АНТИКРИЗИСНОГО УПРАВЛЕНИЯ ПРЕДПРИЯТИЙ ТУРИСТИЧЕСКОЙ ИНДУСТРИИ}

В результате проведенного исследования проанализировано современное состояние и проблемы туристической деятельности в Украине. Обоснована целесообразность применения антикризисного управления на отечественных предприятиях туристической индустрии. Предложены антикризисные меры развития туризма.

Ключевые слова: кризисное состояние, антикризисное управление, туристическая отрасль.

Постановка проблеми у загальному вигляді та її зв'язок 3 важливими науковими та практичними завданнями. Ефективність управління підприємствами в нинішніх умовах невизначеності та кризи в основному визначає ефективність функціонування економіки регіону і України в цілому. Тому дослідження механізму управління кризовими ситуаціями на підприємствах туристичної індустрії вважаємо актуальним і доцільним.

Аналіз останніх досліджень, у яких започатковано вирішення проблеми. Теоретичні аспекти антикризового управління підприємствами в умовах кризової ситуації в економіці України та методологічні аспекти діагностики кризи на підприємствах висвітлювались вітчизняними та зарубіжними науковцями: В.О. Василенко [1], Т.С. Клебанова [2], Б.Р. Кошова [3], О.В. Раєвнєва [4]. Про- 
те формування стратегій антикризового управління підприємств туристичної індустрії потребує подальшого дослідження.

Цілі статті: дослідити чинники та стратегії антикризового управління підприємств туристичної індустрії.

Виклад основного матеріалу дослідження 3 повним обгрунтуванням отриманих наукових результатів. Кризовий стан будь-якого підприємства вважається одним із дестабілізуючих чинників його господарської діяльності в майбутньому. Виникає він внаслідок невизначеності ситуації та ризикованого управління, а також внаслідок виникнення дестабілізуючих чинників зовнішнього середовища, пов'язаних із нестабільністю політичної та економічної ситуації в окремому регіоні та в країні загалом. Тому наявність механізмів та стратегій, які можуть допомогти підприємствам своєчасно діагностувати кризовий стан і запобігти його ще до досягнення критичної межі в нинішніх умовах функціонування має важливе значення у їх діяльності.

Враховуючи постійний вплив різноманітних загроз появі кризових ситуацій, які зумовлюються динамічністю зовнішнього середовища функціонування господарюючих суб'єктів туристичної індустрії, а також впливом політичних та економічних чинників, існуюча система управління вимагає удосконалення та пошуку нових сучасних механізмів управління. 3 цього приводу вважаємо необхідною складовою системи управління повинна стати стратегія управління кризовими ситуаціями, яка дала б можливість на окремих етапах та окремих ділянках господарювання управляти гострими ситуаціями, які потенційно загрожують нормальній роботі та подальшому розвитку підприємств туристичної індустрії.

Практика доводить, що система антикризового управління підприємствами туристичної індустрії повинна грунтуватися на постійному моніторингу чинників внутрішнього та зовнішнього середовищ, виявленні загроз та кризових ситуацій внаслідок їх дії, i в результаті - врахування цих загроз при реалізації стратегій розвитку підприємств. У цьому зв'язку, вважаємо, що існуюча система управління вимагає удосконалення наявних стратегій управління господарською діяльністю підприємств туристичної індустрії в Україні. Різноманітність послуг в туристичній індустрії та особливості їх надання зумовили розвиток різних типів суб'єктів підприє- 
мництва, а також державних та некомерційних організацій, які забезпечують діяльність підприємств цієї галузі.

Глобалізація суспільно-економічних відносин призвела до виникнення ряду загроз - екологічних, економічних, фінансових, військових тощо. Компоненти макрорівня забезпечують життєдіяльність держави загалом та можуть набувати міжнародного значення не лише у питаннях розвитку туризму. Туристична сфера не $\epsilon$ винятком, а їі функціонування безпосередньо чи опосередковано залежить від стану та захисту критичної інфраструктури.

Дослідження показали, що за останні роки динаміка макроекономічних показників негативно позначилась на рівні життя громадян. Рівень оплати праці залишається нижчим за середнє значення по Україні, а частка безробітних є вищою. Здійснюючи туристичну подорож, середньостатистичний турист стикається не лише iз необхідністю дотримання законодавчої бази відповідної країни, а й iз мовним бар'єром. Проте хоч і туристичні потоки є нестабільними, та розвиток туристичної інфраструктури зберігає стійку позитивну тенденцію. Розвиток туризму позитивно впливає на соціально-економічний стан регіону та країни.

Аналіз показав, що існує високий рівень кореляції між показниками ефективності функціонування туристичної сфери та соціально - економічними змінами.

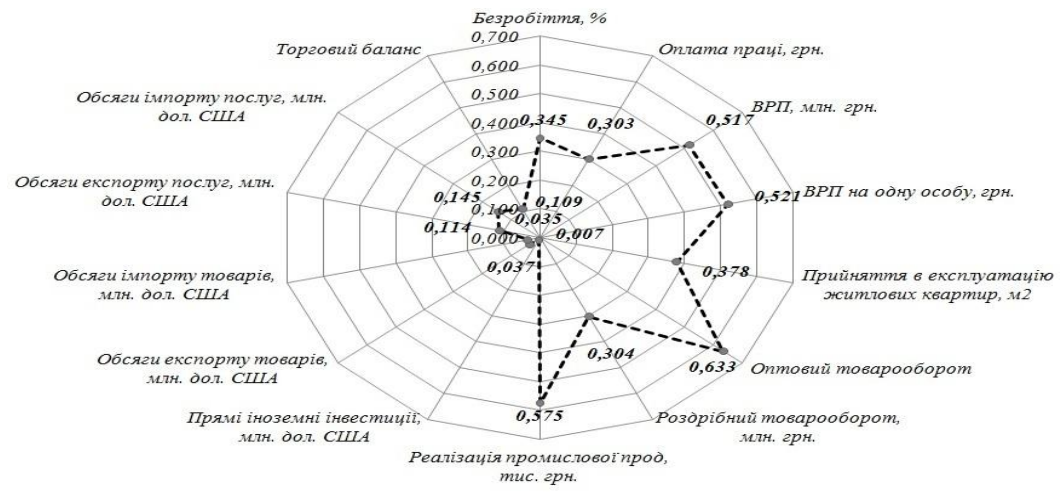

Рис. 1. Коефіцієнти кореляції між показниками соціальноекономічного розвитку та загальною кількістю туристів, які відвідали західні області України за період 2010-2016рp. [3] 
Згрупувавши показники соціально-економічного розвитку, які найбільше впливають на динаміку туристичних потоків, вдалось виявити, що промисловість, торгівля та будівельна сфера більшою мірою залежать від динаміки розвитку туристичної сфери. Загалом можна зазначити, що показники соціально-економічного розвитку впливають на туризм сильніше, ніж туристична інфраструктура. На стан безробіття, рівень оплати праці та зовнішньоекономічну діяльності рівень розвитку туризму майже не впливає. Проте з іншого боку, ці чинники, а особливо, негативна їх динаміка, негативно позначаються на результатах господарювання підприємств індустрії туризму, іноді навіть зумовлюють виникнення кризового стану.

Як показали дослідження праць сучасних науковців, концепція антикризового управління включає в себе чотири блоки проблем: проблеми, які стосуються управління на різних фазах циклічного проявлення кризового розвитку; які пов’язані зі сферами управління; проблеми процесуальності управління: прогнозування криз та оцінка кризових ситуацій, готовність до ризику та передбачення можливих його наслідків; проблеми соціально-економічного характеру: поведінка підприємства на ринку та управління персоналом [1]. Виходячи $з$ даних проблем, основними аспектами антикризового управління є: аналіз симптомів і прогнозування кризи; розробка фінансово-економічного механізму управління кризовими процесами; нормативно-правове регулювання розвитку кризи; менеджмент в умовах кризової ситуації або загрози кризи.

Висновки. На основі вищевказаного, під антикризовим управлінням необхідно розуміти організоване, комплексне управління, яке передбачає оптимальне використання спеціальних інструментів, методів і засобів управління та здатне забезпечити ефективне функціонування господарського суб' єкта в умовах невизначеності та кризи. Антикризове регулювання діяльності підприємств туристичної індустрії, а саме забезпечення її ефективності на усіх стадіях господарювання з метою недопущення тривалих періодів кризи вбачається у тісній взаємодії вищих державних органів влади із місцевими владними органами та приватним сектором, які функціонують у системі надання туристичних послуг. 
1. Василенко В. О. Антикризове управління підприємством / Василенко В. О. К. : Центр навчальної літератури, 2005. - 504 с.

2. Клебанова Т.С. Механізм та моделі управління кризовими ситуаціями на підприємствах житловокомунального комплексу : монографія / Т. С. Клебанова, М. О. Кизим, Ю. І. Мізік. - Х. : ВД «ІНЖЕК», 2011. - 184 с.

3. Кошова Б.Р. Соціально-економічний розвиток туристичної інфраструктури / Б.Р. Кошова // Дисертація на здобуття наук. ступ. канд.. економ. наук. - Львів. $-2018$.

4. Раєвнєва О.В. Моделювання фінансової діагностики стану підприємства / О.В. Раєвнєва, С.О. Степуріна // Економіка і регіон. - 2005. - №3 (6). - С. 74 - 80.

*УДК 332.14

Кондіус I.C., к.е.н., доцент

Луцький національний технічний університет

\section{ТЕОРЕТИЧНІ ЗАСАДИ ДОСЛІДЖЕННЯ ЕФЕКТИВНОСТІ КОРПОРАТИВНОГО УПРАВЛІННЯ КОМЕРЦЙИНОГО БАНКУ}

У статті запропоновано методичні підходи до аналізу та оцінки рівня ефективності корпоративного управління комерційного банку. Запропонована методика забезпечує комплексний підхід до оцінки ефективності функціонування та корпоративного управління банку, дає змогу здійснити всебічний та змістовний аналіз функціонування банківської системи та дослідити досягнутий рівень ефективності корпоративного управління банком, визначити тенденції розвитку банку, виявити та оцінити наявний ресурсний потенціал економічного зростання в майбутньому, дослідити основні позитиви, недоліки та проблеми, диспропорції у функціонуванні банківської системи.

Ключові слова: комерційний банк, корпоративне управління.

Kondius I.

\section{THEORETICAL BASES OF THE STUDY OF THE EFFICIENCY OF CORPORATE GOVERNANCE OF THE COMMERCIAL BANK}

In today's economic conditions, banks operate in a market characterized by the presence of significant competition, and the benefits in competition will take and an organization in which the management system can effectively cope with all the difficul-

* Кондіус I.C. 